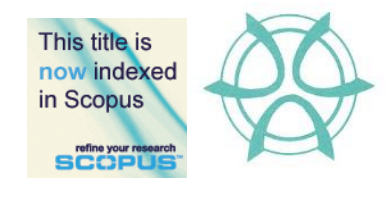

PLANNING MALAYSIA:

Journal of the Malaysian Institute of Planners

VOLUME 16 ISSUE 1 (2018), Page 105 - 117

\title{
DISASTER RISK MANAGEMENT IN MALAYSIA: ISSUES AND CHALLENGES FROM THE PERSEPCTIVE OF AGENCIES
}

\author{
Noraini Omar Chong ${ }^{1} \&$ Khairul Hisyam Kamarudin ${ }^{2}$ \\ ${ }^{1,2}$ UTM Razak School of Engineering and Advanced Technology \\ UNIVERSITI TEKNOLOGI MALAYSIA
}

\begin{abstract}
Disaster is a major threat that could jeopardise the development of economic, social and physical elements of a nation as well as the well-being of its people. The damage and loss of property and life caused by disasters are overwhelming and least desired by any country. Review of literature as presented in this research indicated that by having a good disaster risk management (DRM) plan and wellcoordinated efforts and commitment among related disaster management agencies at all levels and local stakeholders, would potentially lead to disaster risk reductions, increase preparedness and response, and reduction of damage to assets and loss of life. With a long list of agencies and aid bodies that are currently involved in various stages of DRM, putting the idea into reality has proven to be highly challenging particularly on establishing good coordination between agencies and with other stakeholders for a more effective DRM process. This paper identified three major issues and challenges in DRM in Malaysia, particularly from the perspective of agencies. These issues and challenges include (1) disaster management planning imbalanced between top-down and bottom-up approaches, (2) lack of coordination in disaster management cycle, with greater focus only on the disaster emergency response stage and, (3) lack of planning of long-term recovery (post-disaster) process, which resulted in low level community and stakeholders' resilience to disasters.
\end{abstract}

Keyword: disaster risk management, issues and challenges in Malaysia, coordination, resilience 
Noraini Omar Chong \& Khairul Hisyam Kamarudin

Disaster Risk Management in Malaysia: Issues and Challenges from the Persepctive of Agencies

\section{INTRODUCTION}

Gearing sustainable development goals (SDGs) into practice is essentially dependent, among others, on the planning and coordination of disaster risk management at various levels of administration. Therefore, the disaster management cycle as well as the top-down and bottom-up approaches have been established over the years and integrated into the disaster risk management (DRM) area (Coetzee \& Van Niekerk, 2012). In Malaysia, management of disaster risks are regulated by Directive No. 20, under the auspice of the National Disaster Management Agency (NADMA). Concurrent with Malaysia's three-tier government administration system, the disaster management hierarchy is also regulated under three different levels, namely federal, state and district (Figure 1) (Chan, 2012; CEDMHA, 2016). Under Directive No.20, there are five (5) stages in the disaster management cycle consisting of prevention, mitigation, preparedness, response, and recovery which promotes practices and accommodates practitioners with multi-disciplinary backgrounds (CEDMHA, 2016). Even with the availability of such legally binding documents, there are pertinent issues that require further attention, as identified in this research. These issues are, (1) imbalanced of planning approaches in disaster risk management between top-down and bottom-up approaches, (2) lack of coordination in executing disaster risk management cycle and (3) lack of long-term planning (particularly for recovery / post-disaster) that resulted in low community and stakeholders' resilience to disasters.

MALAYSIA DISASTER MANAGEMENT STRUCTURE: AT A GLANCE Malaysia is often considered as a country less prone to major disasters. However, as an equatorial climate country, Malaysia is vulnerable to risks such as flooding, landslides and mudslides (CFE-DMHA, 2016; Shaluf \& Ahmadun, 2006). In 1997, the National Security Council (NSC) has formulated a national policy, management mechanism and disaster aid known as the Directive No.20. The NSC, as the leading agency, was given a mandate under the Directive No.20 to coordinate and execute appropriate actions during disasters. However, with the current magnitude of natural disasters occurrence in Malaysia, it becomes obvious that Malaysia may no longer spared from major natural disasters such as earthquakes, floods and tsunami (Khailani \& Perera, 2013; Zahari, Ariffin, Asmawi, \& Ibrahim, 2013). As a result, in October 2015 the federal government has agreed to establish a special agency, National Disaster Management Agency (NADMA), dedicated to DRM and/or other matters related to DRM. Under Directive No.20, all matters related to disasters are managed by three-tier committees namely; the Centre for Disaster Management and Relief Committee (CDMRC) (chaired by the Deputy Prime Minister) at federal level, followed by the State Disaster Management and Relief Committee (SDMRC) (chaired by the Secretary of State); and the District Disaster Management and Relief Committee 
PLANNING MALAYSIA

Journal of the Malaysia Institute of Planners (2018)

(DDMRC) (chaired by the District Officer) (Chan, 2012; CEDMHA, 2016; NSC, 1997) (Figure 1). Under the Malaysia disaster management structure, seven service themes were established including; (1) search and rescue, (2) health and medical services, (3) media, (4) support, (5) security control, (6) welfare, and (7) warnings and alerts. There are 79 agencies have been identified responsible for carrying out activities related to DRM both from a top-down and bottom-up perspective. This long list of agencies contained, among others, 38 federal agencies, 21 state agencies and 17 district agencies and 2 NGOs. These agencies might function on their own, and/or work together with other agencies to execute DRM projects at various levels. The following section discusses three main issues and challenges faced by agencies in DRM derived from the review of the literature. 
Noraini Omar Chong \& Khairul Hisyam Kamarudin

Disaster Risk Management in Malaysia: Issues and Challenges from the Persepctive of Agencies

NMOO-dOI

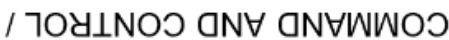

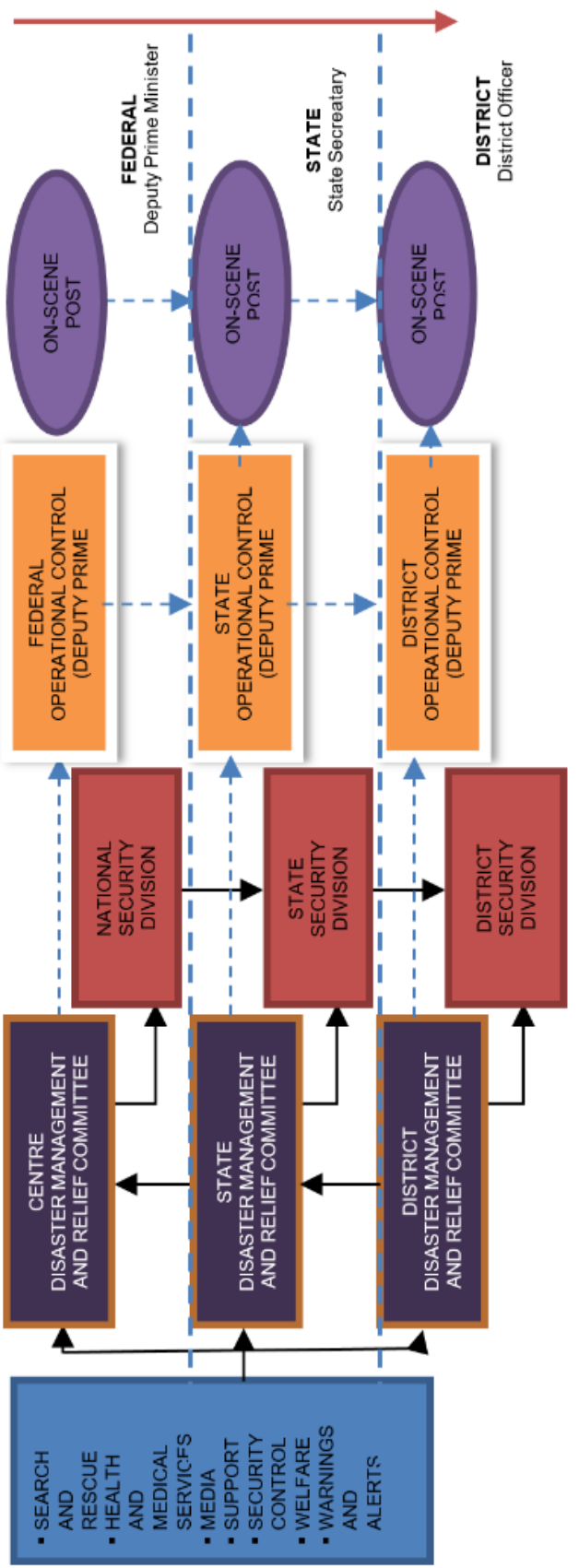

Figure 1: Malaysia disaster management structure Source: Adapted from CFE-DHMA (2016). 
PLANNING MALAYSIA

Journal of the Malaysia Institute of Planners (2018)

\section{ISSUES AND CHALLENGES FOR AGENCIES IN DISASTER RISK MANAGEMENT IN MALAYSIA}

\section{DRM Approaches Imbalance between Top-down and Bottom-up}

According to Chan (1995), the Malaysian government approach for managing disasters is based on a top-down government-centric model where the NSC (under the Prime Minister's Department) will be responsible for matters related to policies on DRM. As mentioned earlier, the CDMRC was established at the federal level to manage and monitor progress and DRM programs at the national level. However, the NSC has three major roles in national security, which are (1) to defend national sovereignty and strategic importance, (2) management of crises and disasters, and (3) border management. With the magnitude of disasters that have occurred in Malaysia recently, it is crucial to have an agency particularly for disaster management. Hence, in 2015, the government established NADMA for managing and coordinating efforts in between various government agencies, host communities and NGOs.

As previously mentioned, there are 79 agencies involved in DRM. The authors then established categorization of the roles of all agencies in DRM into top-down or bottom-up planning approaches based on two main criteria namely (1) agency's compliment to seven themes of DRM services under Directive No.20 which are (a) search and rescue, (b) health and medical services, (c) media, (d) support, (e) security control, (f) welfare, and (g) warnings and alert; and (2) proactive roles and initiatives by agencies that reflected their role as a committee member of CDMRC, including drill exercises for creating public awareness, hazard mapping and zonation, and community-based disaster risk management (CBDRM).

Prior to the categorization process, 11 agencies have been identified as having no specific DRM-related activities that can be related to both criteria, hence be excluded from the list of agencies involvement with DRM cycles. In other words, only 68 agencies remain for further determination of their roles and responsibilities in DRM cycles (Table 1). Review of literature also identified only four agencies namely APM at federal, state and district offices, as well as MERCY possess an integrated bottom-up approach through the implementation of community-based DRM projects which taking into account local knowledge and community involvement in DRM. According to the Deputy Director of the Training Management Division of APM during interview in July 2017, a total of 200 registered members from 200 parliamentary constituencies in Malaysia, which were identified prone to disasters (particularly floods), have been included into CDERTC program. Due to limited capacity for appointing trainers and budget constraints, the training programs and appropriate uniforms which should be supplied to all members of community are still in progress (Director of Awareness and Social Development Division, NADMA, personal 
Noraini Omar Chong \& Khairul Hisyam Kamarudin

Disaster Risk Management in Malaysia: Issues and Challenges from the Persepctive of Agencies

communication, July 2017). Because of these limitations, agencies are having difficulties in upscaling DRM programs, particularly community-based disaster prevention trainings as well as the establishment of CDERTC for the whole country. Similar limitations are also experienced by MERCY i.e. the nongovernmental agency responsible to provide response aid (health and medication) to any affected communities during and immediately after the disaster at the evacuation centre.

\section{Lack of Coordination in Executing Disaster Management Cycle (DMC) between Agencies}

A total of 68 agencies (with exclusion of 11 agencies from the original 79 agencies identified in literature review) have been further determined and categorised in terms of their roles in DRM cycles namely (1) prevention, (2) mitigation, (3) preparedness, (4) response, and (5) recovery. This categorization was carried out based on the ADRC detailed measures involved in each phase in DMC (Table 1 until Table 3).

Table 1: Summary of the roles and responsibilities of agencies according to DRM Cycle - federal level

\begin{tabular}{|c|c|c|c|c|c|}
\hline \multirow[b]{3}{*}{ List of agencies } & \multicolumn{5}{|c|}{ DRM cycle } \\
\hline & \multicolumn{2}{|c|}{ Pre-disaster } & \multicolumn{3}{|c|}{ Post-disaster } \\
\hline & 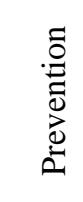 & 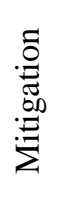 & 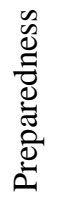 & 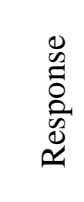 & 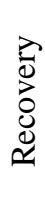 \\
\hline \multicolumn{6}{|l|}{ Agencies at Federal Level } \\
\hline 1. Malaysia Armed Force (ATM) & & & $\checkmark$ & $\checkmark$ & \\
\hline 2. Royal Malaysia Police (PDRM) & & & $\checkmark$ & $\checkmark$ & \\
\hline 3. Ministry of Finance & & & $\checkmark$ & $\checkmark$ & $\checkmark$ \\
\hline $\begin{array}{l}\text { 4. Ministry of Women, Family and } \\
\text { Community Development }\end{array}$ & & & $\checkmark$ & $\checkmark$ & \\
\hline $\begin{array}{l}\text { 5. Ministry of Communication and } \\
\text { Multimedia }\end{array}$ & & & & $\checkmark$ & \\
\hline 6. Ministry of Tourism and Culture & & & & $\checkmark$ & \\
\hline 7. Ministry of Health Malaysia & & & $\checkmark$ & $\checkmark$ & \\
\hline $\begin{array}{l}\text { 8. National Disaster } \\
\text { Management Agency } \\
\text { (NADMA) }\end{array}$ & $\checkmark$ & $\checkmark$ & $\checkmark$ & $\checkmark$ & $\checkmark$ \\
\hline $\begin{array}{l}\text { 9. Fire and Rescue Department } \\
\text { Malaysia (JPBM) }\end{array}$ & & & $\checkmark$ & $\checkmark$ & \\
\hline
\end{tabular}


PLANNING MALAYSIA

Journal of the Malaysia Institute of Planners (2018)

\begin{tabular}{|c|c|c|c|c|c|}
\hline \multirow[b]{3}{*}{ List of agencies } & \multicolumn{5}{|c|}{ DRM cycle } \\
\hline & \multicolumn{2}{|c|}{ Pre-disaster } & \multicolumn{3}{|c|}{ Post-disaster } \\
\hline & 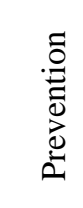 & 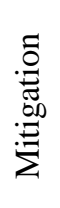 & 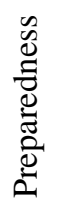 & 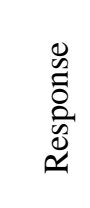 & 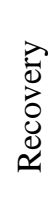 \\
\hline $\begin{array}{l}\text { 10. Malaysia Civil Defence Force } \\
\text { (APM) }\end{array}$ & & & $\checkmark$ & $\checkmark$ & \\
\hline $\begin{array}{l}\text { 11. Malaysian Maritime } \\
\text { Enforcement Agency (MMEA) }\end{array}$ & & & & $\checkmark$ & \\
\hline $\begin{array}{l}\text { 12. Federal Department of Town } \\
\text { and Country Planning } \\
\text { Department Peninsular Malaysia }\end{array}$ & & & $\checkmark$ & & \\
\hline 13. Department of Broadcasting & & & & $\checkmark$ & \\
\hline 14. Department of Information & & & & $\checkmark$ & \\
\hline 15. Public Works Department & $\checkmark$ & $\checkmark$ & $\checkmark$ & $\checkmark$ & $\checkmark$ \\
\hline 16. Department of Environment & & & $\checkmark$ & & \\
\hline 17. Department of Social Welfare & & & $\checkmark$ & $\checkmark$ & \\
\hline $\begin{array}{l}\text { 18. Department of Meteorology } \\
\text { Malaysia (METMalaysia) }\end{array}$ & & & $\checkmark$ & $\checkmark$ & \\
\hline $\begin{array}{l}\text { 19. Department of Civil Aviation } \\
\text { Malaysia }\end{array}$ & & & & $\checkmark$ & \\
\hline $\begin{array}{l}\text { 20. Department of Irrigation and } \\
\text { Drainage (JPS) }\end{array}$ & $\checkmark$ & $\checkmark$ & $\checkmark$ & $\checkmark$ & $\checkmark$ \\
\hline 21. Atomic Energy Licensing Board & & & & $\checkmark$ & \\
\hline $\begin{array}{l}\text { 22. Mineral and Geoscience } \\
\text { Department Malaysia }\end{array}$ & & & $\checkmark$ & & \\
\hline $\begin{array}{l}\text { 23. Volunteers Department of } \\
\text { Malaysia }\end{array}$ & & & $\checkmark$ & $\checkmark$ & \\
\hline $\begin{array}{l}\text { 24. Department of Occupational } \\
\text { Safety and Health Malaysia }\end{array}$ & & & & $\checkmark$ & \\
\hline 25. Department of Water Supply & & & & $\checkmark$ & $\checkmark$ \\
\hline $\begin{array}{l}\text { 26. Attorney General's Chambers of } \\
\text { Malaysia }\end{array}$ & & & & $\checkmark$ & \\
\hline $\begin{array}{l}\text { 27. Malaysian Communications and } \\
\text { Multimedia Commission }\end{array}$ & & & & $\checkmark$ & \\
\hline
\end{tabular}

Source: Review of literature (Department of Mineral and Geoscience Malaysia, 2017; PLANMalaysia, 2016a \& 2016b; Malaysia Drainage and Irrigation Department, 2017; MERCY, 2016; Mohamad, Razak, Ahmad, \& Manap, 2015; National Security Council, 2012; National Security Council, 1997). 
Noraini Omar Chong \& Khairul Hisyam Kamarudin

Disaster Risk Management in Malaysia: Issues and Challenges from the Persepctive of Agencies

Table 2: Summary of the roles and responsibilities of agencies according to DRM

Cycle - state level

List of agencies

\begin{tabular}{|c|c|c|c|c|}
\hline \multicolumn{5}{|c|}{ DRM cycle } \\
\hline \multicolumn{2}{|c|}{ Pre-disaster } & \multicolumn{3}{|c|}{ Post-disaster } \\
\hline 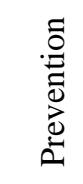 & 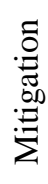 & 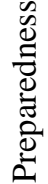 & 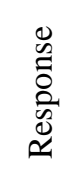 & 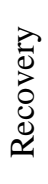 \\
\hline
\end{tabular}

Agencies at State Level

1. State Police

2. Malaysia Armed Force (ATM)

3. State Fire and Rescue Department (JPBM)

4. State Civil Defence Force (APM)

5. State Health Department

6. Malaysian Maritime Enforcement Agency (MMEA)

7. State Public Works Department

8. State Department of Social Welfare

9. State Department of Information

10. State Department of Broadcasting

11. State Education Department

12. State Department of Environment

13. State Meteorological Office

14. State Irrigation and Drainage Department

15. State Mineral and Geoscience Department

16. State Volunteers Department (RELA)

17. State Department of Occupational Safety and Health

18. State Department of Water Supply 
PLANNING MALAYSIA

Journal of the Malaysia Institute of Planners (2018)

\begin{tabular}{|c|c|c|c|c|c|}
\hline \multirow[b]{3}{*}{ List of agencies } & \multicolumn{5}{|c|}{ DRM cycle } \\
\hline & \multicolumn{2}{|c|}{ Pre-disaster } & \multicolumn{3}{|c|}{ Post-disaster } \\
\hline & 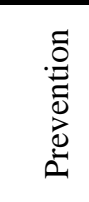 & 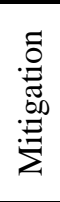 & 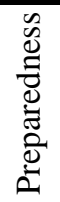 & 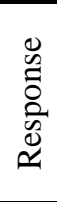 & 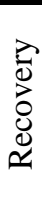 \\
\hline 19. State Telekom Berhad & & & & $\sqrt{ }$ & $\sqrt{ }$ \\
\hline $\begin{array}{l}\text { 20. State Tenaga Nasional Berhad } \\
\text { (TNB) }\end{array}$ & & & & $\checkmark$ & $\checkmark$ \\
\hline 21. State Tourism Malaysia & & & & $\checkmark$ & \\
\hline $\begin{array}{l}\text { 22. Regional Office of } \\
\text { Communications and } \\
\text { Multimedia Commission }\end{array}$ & & & & r & \\
\hline
\end{tabular}

Source: Review of literature (Department of Mineral and Geoscience Malaysia, 2017; Malaysia Drainage and Irrigation Department, 2017; MERCY, 2016; Mohamad et al., 2015; National Security Council, 2012; National Security Council, 1997)

Table 3: Summary of the roles and responsibilities of agencies and non-governmental organizations (NGOs) according to DRM Cycle - district level

List of agencies

\begin{tabular}{|c|c|c|c|c|}
\hline \multicolumn{5}{|c|}{ DRM cycle } \\
\hline \multicolumn{2}{|c|}{ Pre-disaster } & \multicolumn{3}{|c|}{ Post-disaster } \\
\hline $\begin{array}{l}\stackrel{0}{0} \\
\stackrel{0}{0} \\
\stackrel{0}{0} \\
0\end{array}$ & 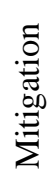 & 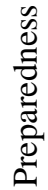 & 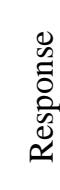 & $\begin{array}{l}\overrightarrow{0} \\
\overrightarrow{0} \\
0 \\
0 \\
0 \\
0\end{array}$ \\
\hline
\end{tabular}

\begin{tabular}{llcl}
\hline Agencies at District Level & & \\
\hline 1. District Police & $\checkmark$ & $\checkmark$ & $\checkmark$ \\
\hline 2. District Office & $\checkmark$ & $\checkmark$ & \\
\hline 3. District Fire and Rescue & $\checkmark$ & $\checkmark$ & \\
Department (JPBM) & & \\
4. District Health Department & $\checkmark$ & $\checkmark$ \\
\hline 5. District Social Welfare Office & $\checkmark$ & \\
\hline 6. District Department of & & \\
Environment & $\checkmark$ & $\checkmark$ \\
\hline 7. Malaysia Armed Force (ATM) & & $\checkmark$ \\
8. Regional Malaysian Maritime & & \\
$\quad$ Enforcement Agency (MMEA) & $\checkmark$ & $\checkmark$ \\
9. Local Authority & $\checkmark$ & $\checkmark$
\end{tabular}
(APM) 


\begin{tabular}{|c|c|c|c|c|c|}
\hline \multirow[b]{3}{*}{ List of agencies } & \multicolumn{5}{|c|}{ DRM cycle } \\
\hline & \multicolumn{2}{|c|}{ Pre-disaster } & \multicolumn{3}{|c|}{ Post-disaster } \\
\hline & 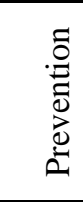 & 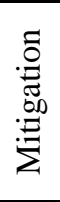 & 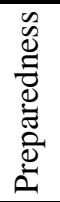 & 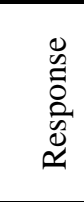 & 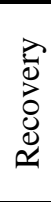 \\
\hline 11. District Information Office & & & & $\sqrt{ }$ & \\
\hline 12. District Education Office & & & & $\checkmark$ & \\
\hline 13. District Public Works Office & $\checkmark$ & $\checkmark$ & $\checkmark$ & $\checkmark$ & $\checkmark$ \\
\hline $\begin{array}{l}\text { 14. District Irrigation and } \\
\text { Drainage Office }\end{array}$ & $\checkmark$ & $\checkmark$ & $\checkmark$ & $\checkmark$ & $\checkmark$ \\
\hline 15. District Volunteers Office & & & & $\checkmark$ & \\
\hline 16. District Telekom Berhad & & & & $\checkmark$ & $\checkmark$ \\
\hline $\begin{array}{l}\text { 17. District Tenaga Nasional } \\
\text { Berhad }\end{array}$ & & & & $\checkmark$ & $\checkmark$ \\
\hline \multicolumn{6}{|c|}{ Non-Governmental Organisation (NGOs) } \\
\hline 18. MERCY & & & $\checkmark$ & $\bar{\checkmark}$ & $\bar{\checkmark}$ \\
\hline $\begin{array}{l}\text { 19. Malaysian Red Crescent } \\
\text { (BSMM) }\end{array}$ & & & & $\checkmark$ & \\
\hline
\end{tabular}

Source: Review of literature ( Malaysia Drainage and Irrigation Department, 2017; MERCY, 2016; Mohamad et al., 2015; National Security Council, 2012; National Security Council, 1997)

The pertinent role and responsibility of various agencies in DMC is summarised and presented in Table 1, 2 and 3. It became obvious that majority of agencies (63 agencies) are involved in disaster response i.e. in the post-disaster phase in DMC. Activities in the response phase could include welfare (food and water), health and medication, and logistic and communication supports which requires preparation (such as in the preparedness phase). On the other hand, a total of 25 agencies are involved in preparedness (pre-disaster) and response (post-disaster) phases. It is worth to highlight that only NADMA, the Public Works Department (PWD) (at the federal, state and district level) and the Department of Irrigation and Drainage (DID) (also at the federal, state and district level) have involved in all five (5) phases of DMC. However, measures taken by the PWD, DID, and MERCY were only in DMC, especially for reconstruction phase (on critical infrastructure such as road, retaining walls and public amenities) whereas no particular measures were taken by these agencies to reconstruct individual assets, such as dwellings.

According to the Pengalaman PKOB Negeri Kelantan: Banjir 2014/2015 (Pengarah Pembangunan Negeri Kelantan, 2015), an estimated 2,805 dwellings were totally destroyed during the 2014 major flood. For undisclosed reason, the reconstruction of new dwellings only achieved 1,176 units based on the budget 
PLANNING MALAYSIA

Journal of the Malaysia Institute of Planners (2018)

allocation by federal government, state government and NGOs. This slow recovery progress shows that the affected communities might be highly vulnerable and not resilient towards disasters as they were not able to recover to their original state (i.e. before disaster strikes).

\section{Agencies' Lack of Planning for Long-Term Recovery (Post-Disaster)}

With reference to the roles and responsibilities of various agencies involved in DRM as presented in Table 4, it is worth mentioning that none of these agencies have actively involved by taking appropriate measures for improving livelihood and individual asset support of the affected communities. As detail out by ADRC, an appropriate and long term measures are needed in reconstruction phase. This is because livelihood support is important to ensure all affected individuals and communities can continue their daily life. In this sense, individuals and communities shall be involved in DRM as a bottom-up approach and to ensure their understanding of DRM cycle, hence able to play their role during disasters.

Table 4: Summary of agencies inclination in DMC - percentage (\%) by DRM phases

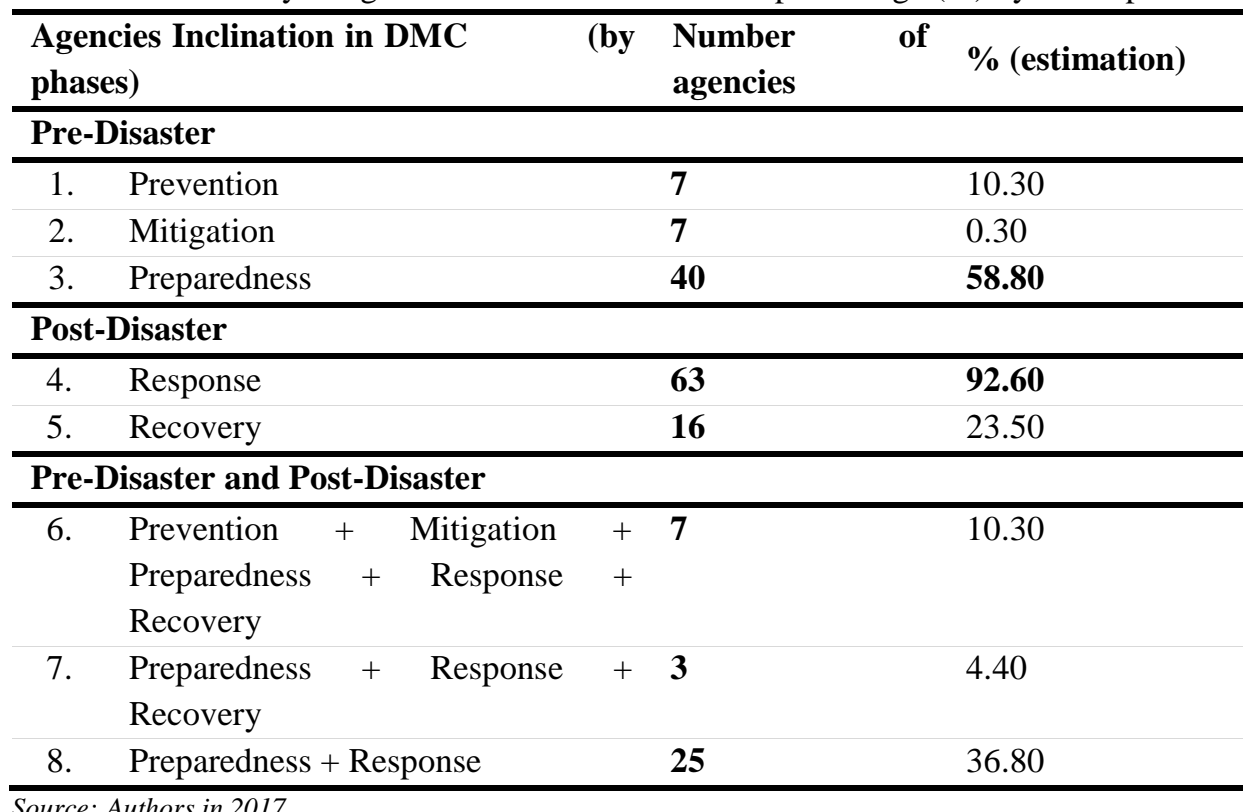


Noraini Omar Chong \& Khairul Hisyam Kamarudin

Disaster Risk Management in Malaysia: Issues and Challenges from the Persepctive of Agencies

\section{CONCLUSION}

The establishment of NADMA in 2015 as a focal point agency for DRM has proven that the government has addressed the need for an appropriate disaster management agency. Various agencies that involve in DRM have been given mandate and responsibilities prior to their appointment as members in CDMRC, SDMRC and DDMRC to carry out measures and activities in DRM under the coordination of NADMA. Each and every agency listed as a disaster management agency shall utilise their resources and expertise for creating desirable impacts to communities affected by disasters. This research however has indicated that more attention are given on expert knowledge and top down approach which might undermine the importance of local knowledge and bottom-up community involvement in strengthening DRM process. Only four (4) agencies were identified as applying bottom-up approach i.e. engaging local communities as compared to over 79 agencies which strongly indicate the use of top-down approach. In addition, only few agencies have their roles and responsibilities clearly stated in DRM, while other agencies only function as committee members. Review of literature also indicated that it is not clearly stated how often the committee shall meet to discuss matters related to disaster management and pertinent issues. Between agencies, such as APM and JKM, they have produced their own standard operating procedures, which could jeopardise the effective coordination among agencies in DRM. With more than 90 percent of agencies focusing on the response phase and almost 60 percent on the preparedness phase, leaving only 30 percent or less for agencies involvement in other phases of the DRM.

\section{ACKNOWLEDGEMENT}

The authors would like to extend their appreciation to the Federal Department for Town and County Planning for their offer of the Federal Training Prize (scholarship), which allowed Mdm. Noraini to pursue her Doctorate of Philosophy study in Universiti Teknologi Malaysia and to make this research and article possible. 


\section{REFERENCES}

Center for Excellence in Disaster Management and Humanitarian Assistance [CFEDMHA] (2016). Malaysia: Disaster Management Reference Handbook 2016.

Chan, N. W. (1995). Flood disaster management in Malaysia: An evaluation of the effectiveness of government resettlement schemes. Disaster Prevention and Management: An International Journal. 4(4), 22-29.

Chan, N.W. (2012). Impacts of disasters and disasters risk management in Malaysia: The case of floods. In Y. Sawada \& S. Oum (Eds.), Economic and welfare impacts of disasters in East Asia and policy responses (pp.503-551). Tokyo: ERIA.

Coetzee, C., \& Van Niekerk, D. (2012). Tracking the evolution of the disaster management cycle: A general system theory approach. Jàmbá: Journal of Disaster Risk Studies, 4(1), 9

Department of Mineral and Geoscience Malaysia (2017). Slope hazard and risk mapping, Malaysia: JMG, KSAASM.

Khailani, D. K., \& Perera, R. (2013). Mainstreaming disaster resilience attributes in local development plans for the adaptation to climate change induced flooding: A study based on the local plan of Shah Alam City, Malaysia. Land Use Policy, 30(1), 615627.

Malaysia Drainge and Irrigation Department (2017). Flood management - programme and activities - flood management in malaysia. Retrieved July 27, 2017 from http://www.water.gov.my/our-services-mainmenu-252/flood-mitigationmainmenu-323/programme-aamp-activities-mainmenu-199?lang=en\&start=1

MERCY (2016). 2016 Annual Report Building Resilience- Empowering Community. Kuala Lumpur: MERCY.

Mohamad, Z., Razak, K. A., Ahmad, F., \& Manap, M. A. (2015, April). Slope Hazard and risk assessment in the tropics: Malaysia Experience. EGU General Assembly 2015. April 12-17, 2015, Vienna, Austria.

Nasional Security Council (2012). Civil defence emergency response team (cdert). Retrieved July 27, 2017 from http://www.civildefence.gov.my/perkhidmatan/civildefence-emergency-response-team-cdert/

National Security Council [NSC] (1997). Directive No.20. Malaysia: National Security Council, Prime Minister Department.

Pengarah Pembangunan Negeri Kelantan (2015). Pengalaman PKOB Negeri Kelantan: Banjir 2014/2015,

PLANMalaysia (2016)(a). National Physical Plan 3. Peninsular Malaysia \& Federal Territories of Labuan: PLANMalaysia, KPKT.

PLANMalaysia (2016)(b). National Rural Physical Planning Policy 2030, Peninsular Malaysia \& Federal Territories of Labuan: PLANMalaysia, KPKT.

Shaluf, I. M., \& Ahmadun, F. -R. (2006). Disaster types in Malaysia: An overview. Disaster Prevention and Management, 15(2), 286-298.

Zahari, R. K., Ariffin, R. N. R., Asmawi, M.Z., \& Ibrahim, A. N. (2013). Impacts of the 2004 tsunami: Preparedness of the Malaysian coastal communities. Procedia - Social and Behavioral Sciences, 105, 569-576 